\title{
EU MULTI-ANNUAL FINANCIAL FRAMEWORK IN THE PERSPECTIVE OF 2021-2027. ASSUMPTIONS AND AREA OF CHANGES
}

\author{
Antoni Kolek* ำ http://orcid.org/0000-0003-3315-1609
}

\begin{abstract}
Background. Preparation of the financial perspective 2021-2027 is to implement the principle of programming the spending of public funds by the EU institutions. Striving to ensure sound management of EU finances by strengthening the rule of law mechanism has become the core value of the new EU budget. The discussion on the EU budget focuses on public policy issues, in particular on aspects such as migration policy and border protection, defense cooperation, climate policy, as well as research and entrepreneurship. In spite of absence from the main stream of the debate, an important part of the EU budget in perspective 2021-2027 will continue to be the common agricultural policy.
\end{abstract}

Research aims. The goal of this article is to analyze the agenda of EU budget assumptions and challenges of EU public policy in political discourse.

Methodology. The comparative method used in the study is the analysis of the differences in the scope of inflows and expenditures of the EU budget. In turn, phenomena and events that affect the wording of the EU budget to a lesser or greater degree have occurred at different times and have had a different impact on the budget adoption process. The timeframe for the analysis presented, including the main factors forming the "two streams", took place in 2015-2018.

Key findings. In the first part of the article, the assumptions of the EU budget for perspective 2021-2027 presented by the Commission were included. The second part of the study is an analysis of the main determinants affecting the revenue and expenditure part of the EU budget. The third part presents the analysis of two streams present in the public discourse: stream of problems, stream of challenges and streams of interests of member states.

Keywords: European Union, budget, EU, Multi-Annual Financial Framework, stream analyses, perspective 2021-2027.

JEL Codes: H61

University of Social Sciences in Lodz, ul. Sienkiewicza 9, 90-113 Łódź, Poland. E-mail: antonikolek@wp.pl 


\section{INTRODUCTION}

The informal meeting of the European Council in February 2018 was the beginning of negotiations on the EU budget for 2021-2027. Summit meeting of the EU heads of state and government indicated that the main goals of the coming period are to reduce illegal migration, strengthen the security of member states, and develop smart specialization, which is to contribute to the EU's economic development. Importantly, at the European Council meeting, some accepted the continuing importance of cohesion policy, the common agricultural policy or pan-European infrastructure.

The description of the procedure for creating the EU budget has been included in the Treaty on the Functioning of the European Union (TFEU 2012). The Treaty contains provisions on the budgetary procedure set out in Articles (310, 313-316) and Article 311 on the financing of the functioning of the EU, and Article 312 on rules of Multiannual Financial Framework. The Council Decision of 26/05/2014 on the EU's own resources system is fundamental for the way the EU budget is determined. Another legal act that shapes the EU's financial policy is the Council Regulation defining the EU's Multi-Annual Financial Framework. The Regulation is adopted by the Council unanimously, with the consent of the Parliament, by a majority of votes. Importantly, the new Multiannual Financial Framework (MFF) must be agreed unanimously, which, in the face of changes on the European political scene, increases the likelihood that inertia will stop radical changes. It is necessary to rethink the EU budget in the context of changing conditions related to security, turmoil in the EU's neighborhood, immigration pressure, cohesion policy or doubts about the effectiveness of a large share of EU spending.

The Commission, which has the right of initiative of the MFF, indicates that it has carefully listened to the remarks of the European Parliament, Member States, national parliaments, beneficiaries of EU funding and other interested parties. More than 11,000 responses were collected during public consultations conducted earlier this year.

Therefore, what is the subject of the public debate around the MFF is of great importance for the future of the EU. It is important not only to hear different parties' views but also to understand the special, additional and complementary nature of the EU budget. It becomes important then which EU public tasks are able to implement 
in a more effective way than each of the member states separately. In the MFF debate, it is also crucial to identify individual streams of public debate in order to be able to consider: problems, solutions and interests of individual states in an orderly and comparable manner.

\section{METHOD}

The comparative method used in the study is the analysis of the differences in the scope of inflows and expenditures of the EU budget. In turn, phenomena and events that affect the wording of the EU budget to a lesser or greater degree have occurred at different times and have had a different impact on the budget adoption process. The timeframe for the analysis presented, including the main factors forming the "two streams", took place in 2015-2018.

\section{RESULTS}

\section{EU Multi-Annual Financial Framework 2021-2027 - Commision proposal}

The concept of EU revenue corresponds to the cash method. This means that the income of a given budget year is recognized in the accounting books based on the amounts collected during the given budget year. The total EU budget per year is slightly more than 1\% of EU GNI and needs to be balanced. This means that there is no possibility of permanent accumulation of debt.

On the other hand, budgeting under EU funds covers diversified funds under which authorizations to incur liabilities and payments are made, as well as non-differentiated appropriations related to covering expenditure financing interventions on agricultural markets, administrative expenses or direct payments. As a result, the method of budgeting in the EU is called a commitment-based budgeting system and relies on managing the expenditure side of the budget by incurring liabilities and paying off the payments.

The EU annual budget is made up of funds from EU Member States, the main own funds are:

- traditional own resources, i.e. the fees and customs receipts, 
- income based on value added tax, determined as a share of VAT collected in a Member State,

- an extract from the GNI of the Member States, which is determined annually and is intended to cover the financing of tasks not covered by other sources of financing.

It is also worth adding that the additional revenues of the EU budget arise from fines imposed by the Union. In addition, due to the conditions negotiated by the United Kingdom for discharging the full amount of payments into the EU budget, please indicate the "UK rebate" as a specific solution affecting the amount of the EU budget. Funds flowing into the EU budget are used to pursue common European policies (European Commission, 2018).

In the case of the analysis of the EU budgetary fiction, one of the key guesses is to correctly distinguish between the budget and the financial perspective. In the case of the budget, it is one-year and its structure in a horizontal aspect include the set-off of income and expenditure, and in the vertical aspect it consists of titles and chapters. Under these criteria, the EU budget becomes an instrument to achieve specific goals for a given budget year. In turn, the MFF's goal is to ensure that EU spending is made in a way that is kept up and within the limits of own resources. This means that the annual EU rapids must be compatible and follow the WRF provisions.

It is worth noting that until now the largest expenditure category within the annual budget is the Common Agricultural Policy (CAP), and then expenditure related to the Structural and Cohesion Funds. These funds represent $72 \%$ of EU commitment appropriations (around EUR 775 billion in 2014-2020). The third-in-the-bucket element of the EU budget is the "Competitiveness for growth and employment" section, which covers almost EUR 143 billion. The fourth largest department is the Administration, which covers the operating costs of the EU institutions worth 70 billion euros. In turn, 66 billion euro will be in the years 2014-2020 for tasks related to "Global Europe". The "Security and Citizenship" section covering public policy issues such as health, consumption, justice and asylum policy covers EUR 18 billion, and actions in the area of "Sustainable growth: natural resources" will receive EUR 11 billion, mainly for maritime and fisheries activities (Council Regulation, 2014).

The most important message from the consultations conducted by the Commission indicates that the desired direction of action is a more united, stronger and more democratic Europe. The Commission's 
thorough expenditure review has highlighted solutions that have worked well in the past, as well as areas where reform is needed. Based on this assessment, the Commission proposes the following MFF rules: emphasis on European added value in relation to public expenditure at the national level more transparent budget less bureaucracy for beneficiaries by means of a single set of rules more flexible budget to be able to react quickly and effectively to unforeseen demands. Budget that brings results in practice by placing more emphasis on results in all programs priorities (European Commission, 2018).

The Commission proposes that the budget in 2021-2027 be EUR 1135 billion, or $1.11 \%$ of the EU's gross national income.

In addition to previous actions and priorities, the Commission states that one of the key tasks is a stable euro area. As part of the plan to deepen the Economic and Monetary Union in Europe, the Commission proposes new budgetary instruments:

- Reform Support Program, which (EUR 25 billion) is to provide financial and technical support to all Member States for the implementation of reforms, in the context of the European Semester,

- European Investment Stabilization Function, the objective of which will be to maintain the level of investment in case of major economic shocks. The instrument, valued at around EUR 30 billion, is to provide additional financial support at a time when public finances are extended and priority investments must be maintained.

In order to reduce the current investment gap in the area of digital technologies, the Commission proposed the creation of a new "Digital Europe" program, aimed at shaping and supporting the transformation of the digital society and the European economy

The Commission is also proposing the creation of a new Fund "Justice, Law and Value", covering programs "Rights and Values" and "Justice", which will result in the continuation of support for creating a European area of justice and cross-border cooperation.

In addition, the Commission will set up a new, fully integrated investment fund, InvestEU, whose task will be to gather all centrally managed financial instruments inside the EU.

At the same time, the Commission concludes that for the most popular and effective programs, such as Erasmus + and the European Solidarity Corps, the budget will be doubled. 
New priorities for EU public policy measures also require new budget revenues. Therefore, the Commission proposes to finance them by combining new revenues (around 80\%) and transfers and savings (around 20\%). Commission proposes to modernize and simplify the current general financing - "Own resources" - the system and diversify the sources of budget revenues. The Commission's proposal provides for a simplification of the Own Resource based on Value Added Tax (VAT), as well as the introduction of new revenues including:

- $20 \%$ of revenues from the emission allowance trading system,

- a 3\% call rate applied to the new Common Consolidated Corporate Tax Base (introduced gradually after the adoption of the necessary provisions).

Commission purpose also National contribution calculated on the basis of non-recyclable plastic packaging waste in each Member State (0.80 EUR/kg) and also according to the Commission's estimates, new resources account for around $12 \%$ of the total EU budget, which means about EUR 22 billion per year to finance new priorities (European Commission, 2018).

\section{Analysis of the main determinants and areas of changes}

The first and most important challenge in the new financial perspective is to fill the hole that Great Britain leaves. According to the Commission's estimates, the gap in revenues from Brexit will be estimated at EUR 12-14 billion per year. The consequence of the loss of income will be cuts in such areas as the common agricultural policy or cohesion policy. According to the Commission's proposals, spending cuts will reach $5 \%$ in agriculture and $7 \%$ in cohesion policy.

According to the public finance theory and experience of fiscal federations, the key direction of EU expenditure reform should be to focus on more efficient delivery of public goods. In line with the Darvas and Wolff concepts, to this end, more independent assessments of different EU programs should be made, as well as an overall allocation of EU budget resources. The emergence of new priorities in the MFF 2021-2027 and the loss of one of the budget payers (Great Britain) will generate higher levels of commitment than other countries (Darvas \& Wolff, 2018).

In the field of research, the Commission proposes the introduction of a new European "Horizon Europe", which aims to finance research and 
compete with other economies. This program is to focus on innovation, development of prototypes, transfer of knowledge and technology.

The Commission notes that in the area of cohesion policy, although the regions of the EU countries differ significantly in terms of economic and social conditions, convergence has been observed in recent years. However, in the case of some regions of relatively wealthy countries, the differences have deepened in recent years. According to the Commission, these trends should be reflected in the new cohesion policy, so that no region is left behind.

Although the relative level of gross domestic product per capita will remain the main criterion for the allocation of funds, the second criterion concerning the unemployment rate, and also the level of education, climate change and activities related to the admission and integration of migrants. may be introduced.

In view of the need to ensure respect for the rule of law, the Commission proposes a link between EU funding and the assessment of respect for the rule of law by the Member State. Due to the belief that respect for the rule of law is a condition for sound financial management and effective EU funding, the Commission calls for a mechanism to protect the EU budget from financial risks related to generalized problems in the area of the rule of law

Changes in the area of climate and environmental protection will also change. The new standards proposed by the Commission will require a higher level of ambition in the field of environment and climate, by tightening the conditions for granting direct payments. An important criterion for granting payments will be actions consistent with environmental objectives, conducive to climate and environmental protection. In addition, in order to counteract shocks and crises in the agricultural sector, a new crisis reserve is planned.

\section{Stream of problems}

In the context of the MFF negotiations, observers testify that the most important goal of each Member State is to maximize profits from the EU budget, as well as to minimize their respective share in national contributions. Therefore, the important task of the Commission is to properly justify the planned expenses and to look for common interests of the Member States, while applying the criterion of task effectiveness. 
In the first report of the High Level Group on Own Resources, presented at the end of 2014, a broad analysis of the current system of financing EU tasks has been concluded. The Group's main objective is to examine the conditions and problems, as well as to indicate how the revenue side of the EU budget can become simpler, transparent, fair and democratically accountable.

With the end of March 2019, when the United Kingdom withdraws from the EU, the issue of UK contributions to the EU budget, as well as other related aspects such as UK correction, will not be justified. Britain's exit from the EU is about EUR 12 billion less per year in the EU budget. It is worth noting, however, that the ongoing negotiations regarding the principles of exit from the EU may give additional funds to the EU as an equivalent for the possibility of access to the common market of EU countries. However, it is difficult to estimate the UK contribution to complete the negotiations.

As Marzinotto points out, the assessment of the effects of spending regional funds depends on the methodology and research intended. Constructed econometric models indicate that Regional Policy financial instruments such as the European Regional Development Fund (ERDF, $55 \%$ ), the European Social Fund (ESF, 23\%), the Cohesion Fund (20\%) and, sometimes included, the Youth Employment initiative (1\%) do not always translate into a positive, though often small, impact of EU funds on convergence. Based on the experience of previous perspectives, it is pointed out that investment in infrastructure brings less benefits to convergence than investments in human capital and research (Marzinotto, 2012).

Noting the achievements of Heinemann, he claims that the EU budget finances too many projects with dubious added value. Being aware that some of them are justified only through political decisions. It is worth noting that the Common Agricultural Policy and Cohesion Policy more often meet local needs rather than objectives at the level of the entire EU (Heinemann, 2015).

\section{Stream of challenges}

One of the elements of the discourse concerned whether the EU budget revenues should increase in the perspective of 2021-2027 above the current level expressed as $1.23 \%$ of GNI. Another solutions proposed by the Commission is the unification of the issue of EU own revenue 
at the level of Member States' legislation. At present, the EU's own resources continue to be recognized in the Member States as a national transfer or 'cost' and not as a 'resource' held by the EU. In the first stage of unification, the Commission proposes greater transparency of the procedures for transferring funds to the EU budget as well as ensuring a clear and standard definition of EU contributions in the systems of the Member States.

However, it should be emphasized that the representatives of many Member States have expressed quite clear opposition to increasing their contribution to GNI. Hence, among the proposals that were present in the discourse there were such possibilities of increasing the EU budget revenues as a $\mathrm{CO} 2$ tax, which would not only be a welcome source of income, but would also be possible without treaty changes in the EU and a sensible way of achieving EU climate goals; or a digital tax that would be covered by virtual enterprises, including the largest technology companies. In the area of revenues, there were also concepts indirectly addressing environmental protection issues. One of the ideas is a partial share or percentage of tax on motor fuel (taxes on fossil fuels / excise duty levied by Member States), another way to increase minimum levels of electricity taxation, which will reduce environmental pollution and stream the lorries to the EU budget.

It is important that the Treaties do not give the EU the power to impose any taxes, and moreover, income tax regulations are not even part of the acquis communitare. At the same time, the provisions of the Treaty on the Functioning of the EU provide the Union with "own resources" to achieve its objectives (Article 311 TFEU), while respecting the fiscal prerogatives of the Member States.

Another important issue is the development of a fiscal stabilization instrument in the euro area, the aim of which would be to respond to uneconomic macroeconomic trends. In the debate on solutions, however, it was not unambiguously determined whether this instrument could be in the EU budget or outside it as a new instrument, e.g. ECB.

\section{CONCLUSIONS}

Referring to the discourse analysis in the area of changes in the MFF, two main currents of the discourse should be distinguished. As part of the stream of problems, it should be pointed out that among the main 
challenges of the EU in the new perspective are activities related to the management of migration within the EU, ensuring internal and external security of the Union, as well as deepening the EU economy's attitude to innovation and the use of scientific research. Other problems that arise as part of the discussion on the future of the EU are the conditions for the UK to leave the EU, preparing the labor market and the EU economy for the aging process, problems with excessive indebtedness of euro countries (in particular: Italy, Spain, Greece) and concerns about the increase in social support for anti-integration or Eurosceptic movements.

In the area of stream regarding potential solutions, there were issues concerning the income and expenditure side of the budget. In the face of technological changes and increasing the activity of virtual enterprises, a digital tax is seen as a potential significant source of income. In turn, due to the process of decarbonization, the use of taxes towards entities aimed at obtaining energy from coal was indicated as a possible solution. In addition, the concept of European added value as a value resulting from EU intervention is a determinant of actions that would generate the most effective way of spending funds from the EU budget. The revenue area would also be increased as a result of increased tax revenues from Member States reporting significant progress. On the other hand, as part of EU spending, a lot of space is devoted to the conditions of using EU funds, as well as areas of activities that should be extended or limited in the context of changing circumstances.

The findings of the informal summit on the MFF priorities for 2021-2027 show that the 27 leaders of the EU Heads of State and Government indicated that the EU budget will spend more on the following priorities:

- management of migration policy,

- defense and security,

- Erasmus + program.

In addition, it should be noted that the process of adopting the MFF may be more complicated by the expected political change in the parliament and the Commission. In order to prevent these risks, it is pointed out that the final session of the current European Parliament, to be held in April 2019, will close the process of adopting the MFF. However, a prerequisite for it to be possible to reach an agreement at the European Council in December 2018. However, it should be noted that the adopted schedule of activities can be considered unrealistic. 


\section{REFERENCES}

Council Regulation (2014). High Level Group On Own Resources. First Assessment Report, Brussels, http://ec.europa.eu/budget/mff/hlgor/library/reports-communication/FirstAssessmentReport-December2014.pdf (accessed: 10th Dec 2018).

Darvas, Z., Wolff, G. (2018). Rethinking the European Union's post-brexit budget priorities. Policybrief, 1, http://aei.pitt.edu/93601/1/PB-2018_01.pdf (accessed: 10th Dec 2018).

European Commission (2018). A New, Modern Multiannual Financial Framework for a European Union that Delivers Efficiently on Its Priorities Post-2020 [The European Commission's contribution to the Informal Leaders' meeting on 23 February 2018', COM(2018) 98 Final], https://ec.europa.eu/commission/ sites/beta-political/files/communication-new-modernmultiannual-financial-framework_en.pdf (accessed: 10th Dec 2018).

Heinemann, F. (2015). Strategies for a European EU Budget, https://www.researchgate. net/profile/Michael_Thoene/publication/292735758_The_Future_of_EU-Finances_-_Synopsis/links/56b0e5d708ae56d7b069be65/The-Future-of-EU-Finances-Synopsis.pdf\#page=91 (accessed: 10th Dec 2018).

Marzinotto, B. (2012). The Growth Effects of EU Cohesion Policy: A Meta-analysis [Working Paper No. 14, Bruege], http://bruegel.org/wp-content/uploads/ imported/publications/WP_2012_14_cohesion_2_.pdf (accessed: 10th Dec 2018). 